[Preprint version] Please cite as : Ishizaka A, Nemery P, Lidouh K, Location selection for the construction of a casino in the Greater London region : a triple multi-criteria approach, Tourism Management, 34(1), 211-220, 2013

\title{
Location selection for the construction of a casino in the Greater London region: a triple multi-criteria approach
}

\author{
Alessio Ishizaka ${ }^{1}$, Philippe Nemery ${ }^{2}$, Karim Lidouh ${ }^{3}$ \\ ${ }^{1}$ University of Portsmouth, Portsmouth Business School, Richmond Building, Portland \\ Street, PO1 3DE Portsmouth, United Kingdom, Alessio.Ishizaka@port.ac.uk \\ ${ }^{2}$ Smart-Picker, Rue Du Trône 180, 1050 Brussels, Belgium, pnemery@gmail.com \\ ${ }^{3}$ Université Libre de Bruxelles, Department of Computer and Decision Engineering \\ (CoDE),1050 Brussels, Belgium, klidouh@ulb.ac.be
}

\begin{abstract}
This work presents a location selection analysis for choosing a suitable borough in the region of Greater London to construct a large casino. Currently 17 of the 26 large casinos in London are located in the borough of Westminster which is known to generate the highest revenue in tourist spending. However, in 2007 the Casino Advisory Panel (CAP) recommended the borough of Newham as the most suitable area for a new casino instead of Westminster. By taking two viewpoints into consideration (one focussed on profitability and the other on social benefits), we evaluate the alternatives using the weighted sum, the TOPSIS and the PROMETHEE methods. The results are compared to the proposals submitted to the CAP for validation. We find that the PROMETHEE and the Weighted Sum Method are more suitable than TOPSIS for solving this problem.
\end{abstract}

Keywords: Multiple criteria analysis, PROMETHEE, TOPSIS, Location analysis, Casino

\section{Introduction}

Site selection is a strategic problem that is regularly encountered in management and marketing studies as is testified by the numerous published articles collected in recent surveys (Farahani, SteadieSeifi, \& Asgari, 2010; ReVelle \& Eiselt, 2005; ReVelle, Eiselt, \& Daskin, 2008; Smith, Laporte, \& Harper, 2009). As in the case of the location of new industrial plants, bank branches, shops, hospitals or schools, the location of a casino is an important decision, because this raises strategic, regional and local considerations 
[Preprint version] Please cite as : Ishizaka A, Nemery P, Lidouh K, Location selection for the construction of a casino in the Greater London region : a triple multi-criteria approach, Tourism Management, 34(1), 211-220, 2013

(Hannigan, 2007). However, this topic has been seldom researched in a multi-criteria context. In this paper, we will review the decision of the Casino Advisory Panel (CAP) in 2007 to recommend Newham as the area in which a large casino should be licensed in Greater London instead of Westminster, which accounts for already 17 out of the 26 existing casinos. This decision has been questioned (Mcmahon \& Lloyd, 2006). Why did the CAP recommend a permission to build in Newham, which has no previous track record of casinos? Why were other boroughs not considered? In this paper, we provide some answer suggestions to these questions using a multi-criteria approach. First, we model the problem based on a literature review of casino location benefits. In a second step, as it is a Multi-Criteria Decision Analysis (MCDA) problem, we apply MCDA methods, which belong to three different families and require minimal subjective input from the decision-makers. This is an essential feature as we do not have access to the original CAP. For these reasons, we select PROMETHEE (for the outranking family), Weighted Sum Method (for the full aggregation family) and TOPSIS (for the distance based family) to solve this location problem. Our analysis shows that the PROMETHEE and the Weighted Sum Method methods support the CAP decision. TOPSIS, however, results in a different recommendation.

\section{Problem description}

The Gambling Act 2005 permitted 17 new casinos to operate in Britain: one regional, eight large and eight small casinos. Only two London boroughs submitted a proposal for a large new casino: Westminster Council and Newham Council.

Westminster's proposal (Hodgson, 2006) highlights the strong assets of the borough: the high revenue generated by tourism, the high proportion of people in the highest socioeconomic categories, the presence of London's iconic attractions and the high concentration of hotels ( $40 \%$ of the hotels in London are in this borough). The presence of already 17 casinos, which represent $75 \%$ of the casinos in London and $14 \%$ in the United Kingdom, ensures a proven location as local inhabitants are accustomed to this type of premises. The social impact of a new casino in such similar environment would be small. There are even a few areas in the borough far from the commercial area that need some regeneration (Figure 1), although probably less than in other places in London. Based on these arguments, the borough of Westminster bid for two additional large casino licenses. 
[Preprint version] Please cite as : Ishizaka A, Nemery P, Lidouh K, Location selection for the construction of a casino in the Greater London region : a triple multi-criteria approach, Tourism Management, 34(1), 211-220, 2013

Newham's proposal (Heraty, 2006) highlights the fact that the borough is in need of regeneration and lies within the Thames Gateway (identified as a national priority for regeneration). Several conclusions of studies and statistics were included to support this observation. Figure 1 shows that Newham lies at the heart of areas needing regeneration and the Council is committed to reduce poverty. It is also London's best connected borough through road, rail and underground and therefore has significant visitor potential. The report stated that it would be ensured that residents of Newham would benefit from the job opportunities generated by the casino.

The Casino Advisory Panel (CAP, 2007) took its decision based on two criteria:

- Area in need of regeneration (as measured by employment and other social deprivation data) and which is likely to benefit in those terms from a new casino.

- Area which wants to license a new casino and is likely to find a company willing to open a casino in the area.

The methodology used is not specified in the report but it is our belief that a consensus decision was reached through internal debate rather than using a specific multi-criteria method. The Casino Advisory Panel has recommended Newham for hosting a new casino.

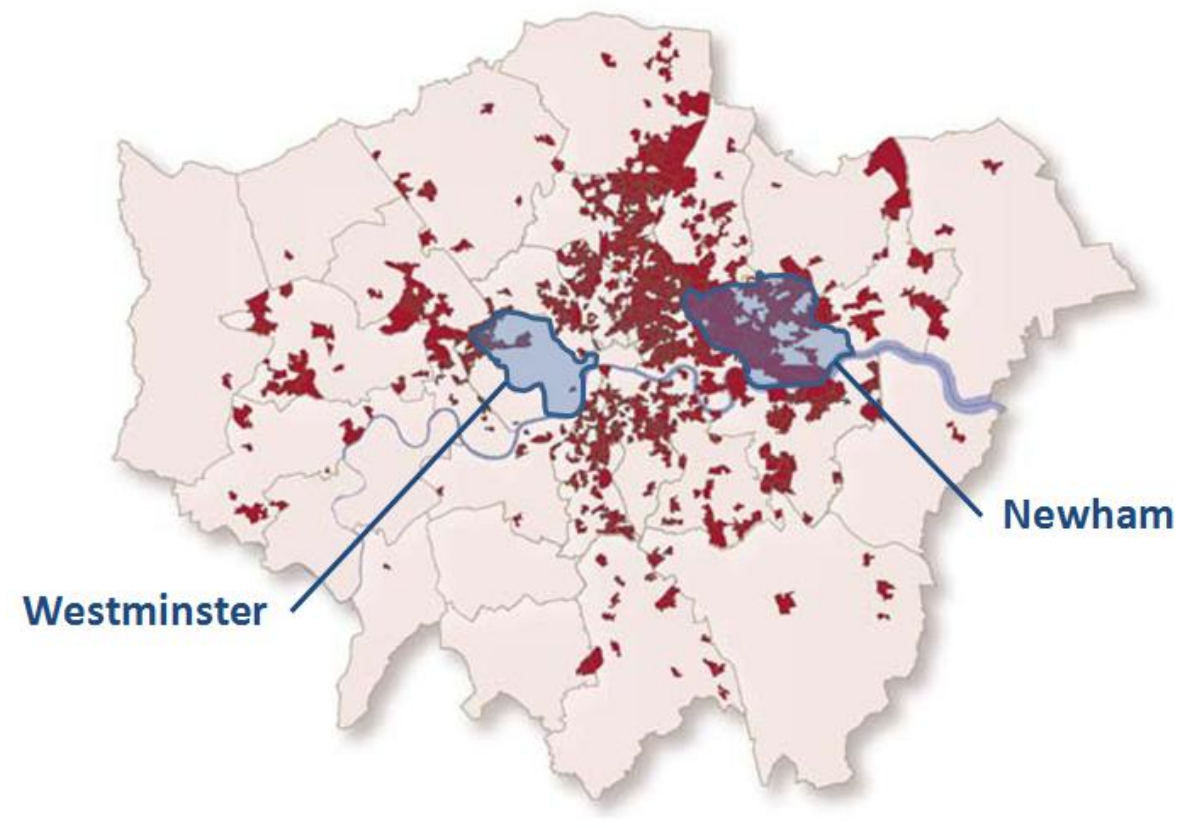

Figure 1: Map of the 20\% most deprived areas in Greater London (Authority, 2009) 
[Preprint version] Please cite as : Ishizaka A, Nemery P, Lidouh K, Location selection for the construction of a casino in the Greater London region : a triple multi-criteria approach, Tourism Management, 34(1), 211-220, 2013

\section{MCDA methods}

\subsection{Introduction}

For our analysis, we used the web application Spatial Decision Support Systems (SDSS) DECERNS. This online tool has already been successful in solving several decisions on land use planning and management (Sullivan, Yatsalo, Grebenkov, \& Linkov, 2009). It incorporates three popular multi-criteria decision methods belonging to different families: PROMETHEE, Weighted Sum Method and TOPSIS. These MCDA methods require a minimal subjective input from the decision-makers, which is ideal in our case as we do not have access to the original CAP advisers. As all these MCDA methods aim to select one action from a set of $m$ possible actions $A=\{a, b, \ldots, m\}$ or to rank them on the basis of $n$ criteria $C=\left\{c_{1}, c_{2}, . ., c_{n}\right\}$, the table of score is entered only once in DECERNS and then particular parameters for each method are selected. The next sections will describe in detail each method used in this study.

\subsection{Weighted Sum Method}

The weighted sum method is the most popular multi-criteria decision method, mainly because of its simplicity. As its name indicates, it is a simple sum of weighted scores (1).

$$
\begin{array}{ll}
p_{a}= & \sum_{i=1}^{n} x_{a i} \cdot w_{i} \\
p_{a}: & \text { priority score of action } a \\
x_{a i}: & \text { normalised score of action } a \text { on criterion } i \\
w_{i}: & \text { weight of criterion } i \\
n: & \text { number of criteria }
\end{array}
$$

\subsection{PROMETHEE}

The PROMETHEE method belongs to the family of the multi-criteria outranking methods (Vincke, 1992). The actions are first pair-wise compared on each criterion according to the decision-maker's preferences, resulting in local scores. These local scores are then aggregated to a global score, which lead to the PROMETHEE I or PROMETHEE II ranking (Brans, 1982; Brans \& Vincke, 1985). In PROMETHEE I, the resulting ranking is a partial pre-order whereas in PROMETHEE II the resulting 
[Preprint version] Please cite as : Ishizaka A, Nemery P, Lidouh K, Location selection for the construction of a casino in the Greater London region : a triple multi-criteria approach, Tourism Management, 34(1), 211-220, 2013

ranking is a complete pre-order. Several successful cases have been compiled in (Behzadian, Kazemzadeh, Albadvi, \& Aghdasi, 2010).

\section{Information within a criterion}

For each criterion $c_{i}$, and for each ordered pair of action, the decision maker expresses his preference by means of a preference degree. The preference degree $P_{i}(a . b)$ indicates if an action $a$ is preferred or not to $b$ on the criteria $c_{i}$ based on the difference between their evaluation $d_{i}(a, b)$. This preference degree is obtained using the preference function which may require different parameters such as the indifference threshold $q_{i}$ and the preference threshold $p_{i}$. If the difference $d_{i}(a, b)$ between the score of action $a$ and $b$ on criterion $c_{i}$ is higher than $p_{i}$, the action $a$ is preferred over $b$. If $d_{i}(a, b)<q_{i}$ then action $a$ and $b$ are indifferent. Formally, we have:

$P_{i}(a, b)=0 \quad$ if $d_{i}(a, b)<q_{i}($ action $a$ is indifferent to $b)$

$P_{i}(a, b)=1 \quad$ if $d_{i}(a, b)>p_{i}($ action $a$ is prefered to $b)$

Several typical shapes are proposed (Brans \& Mareschal, 2005) for the preference functions like the linear, the step or the Gaussian preference function (see Figure 2 for the linear function).

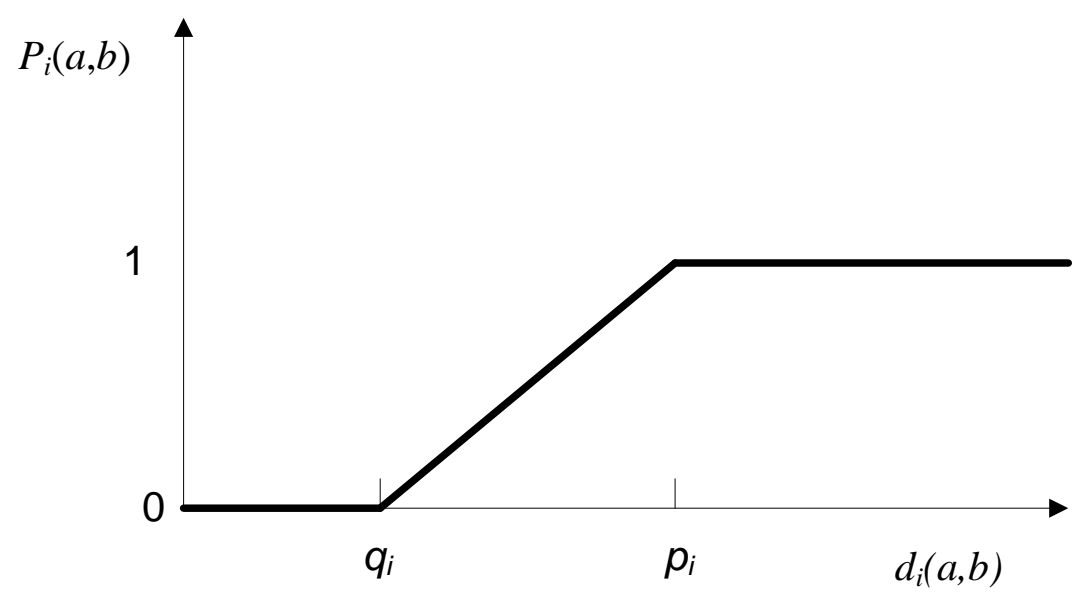

Figure 2: Preference linear function where $q_{i}$ and $p_{i}$ represent respectively the indifference and preference thresholds. $\mathrm{d}_{i}(a, b)$ denotes the difference between the score of action $a$ and $b$ on criterion $c_{i}$. 
[Preprint version] Please cite as : Ishizaka A, Nemery P, Lidouh K, Location selection for the construction of a casino in the Greater London region : a triple multi-criteria approach, Tourism Management, 34(1), 211-220, 2013

\section{Aggregated preference functions}

In order to evaluate how much the action $a$ is preferred to $b$ over all criteria, the preference index $\pi(a, b)$ is calculated with a weighted sum of the preference degrees $P_{i}(a, b)$. The weights $w_{i}$ represents the importance of each criteria in the decision:

$$
\pi(a, b)=\sum_{i=1}^{n} P_{i}(a, b) w_{i}
$$

where, $P_{i}(a, b)$ : preference degree on criterion $i$

$$
\begin{array}{ll}
w_{i}: & \text { weight of criterion } i \\
n: & \text { number of criteria }
\end{array}
$$

If $\Pi(a, b) \approx 0$, it implies a weak global preference or indifference of $a$ over $b$;

$\Pi(a, b) \approx 1$ implies a strong global preference of $a$ over $b$.

\section{Outranking flows}

As each action is compared with $m$-1 other actions, two flows can be defined with (1):

Positive flow:

$$
\begin{aligned}
& \Phi^{+}(a, b)=\frac{1}{m-1} \sum_{x \in A} \pi(a, x) \\
& \text { where, } m: \text { number of actions } \\
& A: \quad \text { the set of the } m \text { actions }
\end{aligned}
$$

This score represents the global preference of action $a$ in comparison to all the other actions. Indeed, this score has to be maximised.

Negative flow:

$$
\begin{aligned}
& \Phi \cdot(a, b)=\frac{1}{m-1} \sum_{x \in A} \pi(x, a) \\
& \text { where, } m: \text { number of actions }
\end{aligned}
$$

$$
A \text { : } \quad \text { the set of the } m \text { actions }
$$


[Preprint version] Please cite as : Ishizaka A, Nemery P, Lidouh K, Location selection for the construction of a casino in the Greater London region : a triple multi-criteria approach, Tourism Management, 34(1), 211-220, 2013

This score represents the global weakness of $a$ in comparison to all the other actions. Indeed, this score has to be minimised.

\section{Ranking}

Based on the positive and negative flows, the PROMETHEE I partial ranking is defined as follows:

- $a$ is preferred to $b$ iif. $\quad \Phi^{+}(a) \geq \Phi^{+}(b)$ and $\Phi^{-}(a)<\Phi^{-}(b)$ or

$$
\Phi^{+}(a)>\Phi^{+}(b) \text { and } \Phi^{-}(a) \leq \Phi^{-}(b)
$$

- $a$ is indifferent to $b$ iif. $\quad \Phi^{+}(a)=\Phi^{+}(b)$ and $\Phi^{-}(a)=\Phi^{-}(b)$

- $a$ is incomparable to $b \quad$ otherwise

However, these two flows are usually combined to obtain the net flows defined as follows:

$$
\Phi(a)=\Phi^{+}(a)-\Phi \cdot(a)
$$

which leads to the complete ranking of PROMETHEE II. The higher the net flows, the better the rank of an action. A deeper discussion on the net flow scores can be found in (Brans \& Mareschal, 2005) and (Mareschal, De Smet, \& Nemery, 2008).

\subsection{TOPSIS}

TOPSIS (Technique for Preference by Similarity to the Ideal Solution) was developed by (Hwang \& Yoon, 1981; Lai, Liu, \& Hwang, 1994; Yoon, 1980). The goal is to simultaneously minimise the distance of an action to an ideal action (an action which has the best scores on all criteria) and maximise the distance from an anti-ideal action (an action which has the worst scores on all criteria). Its advantage is the limited subjective inputs needed from the decision-maker. The only subjective inputs are the weights given to the criteria. The method implemented in DECERNS is the classical TOPSIS based on six steps:

a) The scores of $n$ actions $a$ with respect to $m$ criteria $i$ are collected in a decision matrix $\mathrm{X}=\left(x_{a i}\right)$.

b) The decision matrix is normalised. 
[Preprint version] Please cite as : Ishizaka A, Nemery P, Lidouh K, Location selection for the construction of a casino in the Greater London region : a triple multi-criteria approach, Tourism Management, 34(1), 211-220, 2013

(6)

$$
\begin{aligned}
& r_{a i}=\frac{x_{a i}}{\sqrt{\sum_{a=1}^{m} x_{a i}^{2}}} \\
& \text { for } a=1, \ldots, m \text { and } i=1, \ldots, n
\end{aligned}
$$

The normalisation is necessary to compare criteria measured on different units (e.g. Pounds, years,...).

c) A weighted normalised decision matrix is constructed by multiplying the normalised decision matrix $r_{a i}$ by the criteria weights $w_{i}$.

$$
v_{a i}=w_{i} \cdot r_{a i}
$$

d) An ideal (or zenith) and an anti-ideal (or nadir) action are constructed by collecting the best and worst score on each criterion in the normalised decision matrix.

\section{Ideal action:}

(8)

$$
\mathrm{A}^{+}=\left\{v_{1}^{+}, \ldots, v_{m}^{+}\right\}
$$

where, $v_{i}^{+}=\left\{\max _{a}\left(v_{a i}\right)\right.$, if criterion $i$ is to be maximised; $\min _{a}\left(v_{a i}\right)$, if criterion $i$ is to be minimised\}

Anti-ideal action:

(9) $\quad \mathrm{A}^{-}=\left\{v_{1}, \ldots, v_{m}\right\}$

where, $v_{i}=\left\{\min _{a}\left(v_{a i}\right)\right.$, if criterion $i$ is to be minimised; $\max _{a}\left(v_{a i}\right)$, if criterion $i$ is to be maximised $\}$

e) Calculate the distance for each action to:

- the ideal action:

$$
\begin{aligned}
& d_{a^{+}}=\sqrt{\sum_{i}\left(v_{i}^{+}-v_{a i}\right)^{2}} \\
& \text { where } a=1, \ldots, n
\end{aligned}
$$

- the anti-ideal action:

$$
d_{a}^{-}=\sqrt{\sum_{i}\left(v_{i}^{-}-v_{a i}\right)^{2}}
$$


[Preprint version] Please cite as : Ishizaka A, Nemery P, Lidouh K, Location selection for the construction of a casino in the Greater London region : a triple multi-criteria approach, Tourism Management, 34(1), 211-220, 2013

where $a=1, \ldots, n$

f) Calculate relative closeness coefficient of each action:

(12) $\quad \mathrm{C}_{\mathrm{a}}=\frac{d_{a}^{-}}{d_{a}^{+}+d_{a}^{-}}$

The closeness coefficient is between 0 and 1, where 1 is the preferred action. If an action is closer to the ideal than the anti-ideal action, then $\mathrm{C}_{\mathrm{a}}$ approaches 1 , whereas if an action is closer to the anti-ideal than to the ideal action, $\mathrm{C}_{\mathrm{a}}$ approaches 0 .

Opricovic and Tzeng (2004) have presented one simple example, where an extreme action evaluated on two criteria, is preferred over a superior compromise. We cannot generalise this surprising result but certainly the Euclidean distance (L2) used in (10) and (11), which enlarges high distances (Lai, et al., 1994), may lead to different results than methods based on Manhattan distances (L1).

\section{Casino location problem}

Our model for the new casino location contains two main branches reflecting the two main objectives of the decision (CAP, 2007):

- The first objective is to attract a casino company, therefore the number of customers should be maximised. For this purpose, the profile of the gamblers is defined through a literature search and corresponding criteria are selected.

- The second objective aims to regenerate deprived boroughs, therefore social advantages of a casino are modelled.

\subsection{Profile of a gambler}

This section defines the typical profile of a casino customer. An accurate profile is essential as it allows us to identify the relevant criteria for maximising the profit of a casino in London. According to Goodman (1995), there are two basic types of normal gamblers: convenience and tourist gamblers.

Most academic studies have focused on the negative impacts of gambling and specially on pathological gambling (Afifi, Cox, Martens, Sareen, \& Enns, 2010; McBride, Adamson, \& Shevlin, 2010). The research on gambling has explored why people become 
[Preprint version] Please cite as : Ishizaka A, Nemery P, Lidouh K, Location selection for the construction of a casino in the Greater London region : a triple multi-criteria approach, Tourism Management, 34(1), 211-220, 2013

pathological gamblers rather than why and who are the gamblers in the general population. These researches may have reinforced the negative perception that the public have about gambling as a general activity. However, problem gamblers are a small minority according to studies in UK: 0.6\% (Orford, Sproston, \& Erens, 2003; Wardle, et al., 2007) and 1.4\% (McBride, et al., 2010). This observation is also valid in other countries: 1-2\% in Australia (Walker \& Dickerson, 1996) and 0.5-2\% in Canada (Marshall \& Wynne, 2004) and 3\% in the United States (Kessler, et al., 2008). We will therefore neglect them in this study.

\subsubsection{Convenience gambler}

Convenience gamblers are customers living near the casino. Some surveys have identified the general profile of gamblers. In United Kingdom, the British Gambling Prevalence Survey was undertaken to help the Gambling Commission to understand the nature and scale of gambling in Great Britain and then to regulate the commercial gambling. The first survey has been published in 2000 (Sproston, Erens, \& Orford, 2000) and the second in 2007 (Wardle, et al., 2007). A random sample of 9,003 individuals participated in the second survey, which have been interviewed on several types of gambling activities (National lottery draw, bingo, online gambling, casino, etc). According to the survey, 2 million adults (4\% of the population) gambled in a casino within the last 12 months. Among casino gamblers there are three times more men than women, and men also spend more: £34/week for a man against £3/week for a woman. If we consider only the table games in a casino, young (Table 1), single (Table 2) and white (Table 3) persons represent the majority of the customers.

\begin{tabular}{|c|c|c|c|c|c|c|c|}
\hline Age group [years] & $18-24$ & $25-34$ & $35-44$ & $45-54$ & $55-64$ & $65-74$ & $75+$ \\
\hline Gamblers [\%] & $33^{*}$ & 32 & 16 & 12 & 4 & 4 & 0 \\
\hline
\end{tabular}

* Percentage has been readjusted as the 16-18 years are not allowed to enter a casino

Table 1: Casino customers by age (Wardle, et al., 2007)

\begin{tabular}{|c|c|c|c|c|}
\hline Marital status & $\begin{array}{c}\text { Married / living } \\
\text { as married }\end{array}$ & $\begin{array}{c}\text { Separated / } \\
\text { divorced }\end{array}$ & Single & Widowed \\
\hline Gamblers [\%] & 21 & 21 & 50 & 7 \\
\hline
\end{tabular}

Table 2: Casino customers by marital status (Wardle, et al., 2007) 
[Preprint version] Please cite as : Ishizaka A, Nemery P, Lidouh K, Location selection for the construction of a casino in the Greater London region : a triple multi-criteria approach, Tourism Management, 34(1), 211-220, 2013

\begin{tabular}{|c|c|c|c|c|}
\hline Ethnicity group & White & Black & Asian & Other \\
\hline Gamblers [\%] & 36 & 18 & 9 & 36 \\
\hline
\end{tabular}

Table 3: Casino customers by ethnicity group (Wardle, et al., 2007)

Persons with a higher qualification and a high salary are most likely to visit casinos (Table 4). As both criteria have a strong correlation, we will retain only the educational qualification in our gambler profile.

\begin{tabular}{|l|c|c|c|c|c|c|}
\hline $\begin{array}{l}\text { Highest } \\
\text { educational } \\
\text { qualification }\end{array}$ & $\begin{array}{c}\text { Degree } \\
\text { or } \\
\text { higher }\end{array}$ & $\begin{array}{c}\text { Professio- } \\
\text { nal below } \\
\text { degree }\end{array}$ & A-levels & $\begin{array}{c}\text { GCSEs / } \\
\text { O-levels }\end{array}$ & $\begin{array}{c}\text { Other } \\
\text { quali- } \\
\text { fication }\end{array}$ & $\begin{array}{c}\text { None } \\
\text { quali- } \\
\text { fication }\end{array}$ \\
\hline Gamblers [\%] & 27 & 14 & 27 & 18 & 9 & 5 \\
\hline
\end{tabular}

Table 4: Casino customers by highest educational qualification (Wardle, et al., 2007)

Each Table 1-4 can be utilised to estimate the number of customers in each borough. We used all four separately and calculated an average in the hierarchy (section 4.3).

\subsubsection{Tourist gambler}

Local gamblers are only one portion of the customers. The number of tourist gamblers may be very high, especially in synergistic tourist destinations, characterized by the presence of multiple casinos, thousands of hotels, high quality restaurants, nightclubs and recreational activities such as spas, shopping areas, theatres... The spending levels may change if a new casino is opened in a borough where currently there is no casino. This effect depends if gambling is the primary reason of the travel or a side activity. Recent researches tend to show that tourism gambling is often only a secondary activity. For example, in Las Vegas, almost 100\% of the gamblers were tourists in 2009 (Research, 2009a). However, the first purpose of their visit was for vacation in $40 \%$ of the cases and only 13\% declared to be tourist's gambler. In Laughlin (Research, 2009b), 99\% of the gamblers were tourists in 2009 , but only $20 \%$ were tourists' gamblers, whilst in $48 \%$ of the cases the first purpose of their visit was for vacation. Finally, the mix of games has an influence on the type of customers (Zenke \& Shoemaker, 2009). Local gamblers prefer video poker games, whilst tourists' gamblers play mostly with slots.

In order to quantify the tourism attractiveness of each borough, we will use the tourism spending figure. 
[Preprint version] Please cite as : Ishizaka A, Nemery P, Lidouh K, Location selection for the construction of a casino in the Greater London region : a triple multi-criteria approach, Tourism Management, 34(1), 211-220, 2013

\subsection{Social and urban benefits}

In the United States and Australia, a fundamental justification for casino development has been its potential role as a social, economical and urban development tool (Hannigan, 2007). Cities and regions see the economic benefit of new investments and tax resources, especially if customers are nonlocal, as in any other economic development activity, i.e. tourism, plants, etc (Barrow, Borges, \& Galipeau, 2004; Burmania, 2010; Leven, Phares, \& Louishomme, 1998). Casinos are often considered a catalyst for the development of a tourism industry: restaurants, hotels, live entertainment venues (Felsenstein, Littlepage, \& Klacik, 1999). Their economic benefits have been acknowledged in several studies (Long, 1996; Perdue, Long, \& Kang, 1999; Roehl, 1999). In addition, they could also provide social activities and contribute to the well-being of the local community (Mcmahon \& Lloyd, 2006). However, if a casino development is not coupled with a careful community planning, effective implementation and constant evaluation and reassessment, the local residents may be affected from negative effects, as traffic congestion, noise, car-parking problems and reduction of the affordability of houses (Mcmahon \& Lloyd, 2006). Nevertheless, local residents who perceive personal benefits from having a casino in their community are more likely to support it, which is explained by the social exchange theory (Kang, Lee, Yoon, \& Long, 2008; Lee, Kang, Long, \& Reisinger, 2010).

Residents have recognised that casinos have a positive impact on employment (Long, 1996; Roehl, 1999). The job opportunities are numerous (AGA, 2012; Andersen, 1996; Harrah's, 2000; Rose, 1998):

- Gaming operations: machine technicians, cashiers, dealers, table games supervisors.

- Casino services: security, food and beverages, retail, purchasing, maintenance and facilities specialists.

- Marketing: public relations, market research, advertising professionals.

- Human resources: employee relations, compensation, staffing, training specialists.

- Finance and administration: lawyers, audit, payroll, income control.

It has been estimated that a new casino in Newham could generate about 300 additional jobs (Newham Council, 2006). As the casino will provide training for employees, its presence is beneficial for inhabitants with unskilled jobs. 
[Preprint version] Please cite as : Ishizaka A, Nemery P, Lidouh K, Location selection for the construction of a casino in the Greater London region : a triple multi-criteria approach, Tourism Management, 34(1), 211-220, 2013

On the other side, the common perception is that gambling increases criminal activities. This concern often arises because of the historic connection between gambling and organised crime. However, considerable effort has been done to control organised crime and corruption. Some studies did not find any significant negative changes in unemployment, bankruptcy or crime after casinos opened (Koo, Rosentraub, \& Horn, 2007). Other studies have observed an increase of all types of crimes apart from murders in the post-casino construction (Friedman, Hakim, \& Weinblatt, 1989; Grinols \& Mustard, 2006; Hakim \& Buck, 1989). However, these studies do not take into account the increase of the population. If the resident population and the average daily number of visitors are combined, the proportional crime rate is reduced (Curran \& Scarpitti, 1991) and its net increase is far less than in ski resorts (Park \& Stokowski, 2010). The majority of respondents of surveys do not perceive significant increase in disruptive influences (Stitt, Nichols, \& Giacopassi, 2005). The introduction of National Lottery, scratch cards, on-line gambling and bingo served to popularize and legitimize gambling as a more acceptable social activity (Mcmahon \& Lloyd, 2006).

Another point to consider for the decision is the possibility of synergies with revitalization projects planned by the authorities for the most deprived areas of Greater London (Greater London Authority, 2009). This regeneration technique has been used in several other resorts (Mcmahon \& Lloyd, 2006). The selected borough could thereby benefit from improved transports, improved health and security systems and the presence of additional attractions in the borough, etc.

All the arguments mentioned above will be diluted if a new casino is constructed in a neighbourhood of existing ones. For a maximal impact, a borough with no casino already established is preferred.

\subsection{Criteria hierarchy}

Based on our literature review of the main criteria for casino location (section 4.1 and 4.2), we have constructed a hierarchy of criteria in Figure 3. The next paragraphs explain how the data of Table 5 have been collected. 
[Preprint version] Please cite as : Ishizaka A, Nemery P, Lidouh K, Location selection for the construction of a casino in the Greater London region : a triple multi-criteria approach, Tourism Management, 34(1), 211-220, 2013

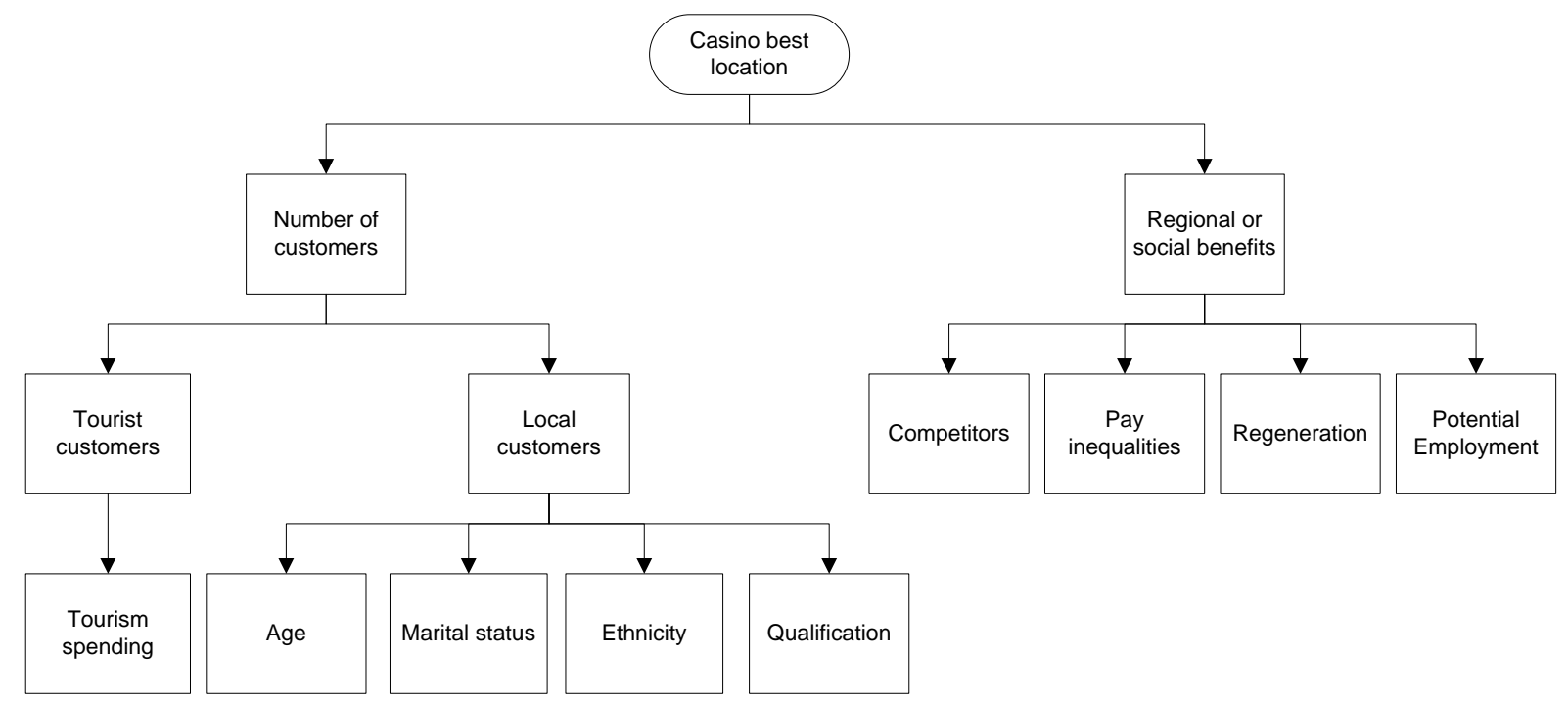

Figure 3: Hierarchy of the criteria

- Tourism spending: As the spending data of tourists in casinos is not publicly available, we have assumed that it is proportional with the Local Area Tourism Impact (LATI) model. The LATI model has been developed by the London Development Agency, in conjunction with Greater London Authority (GLA) Economics. It estimates the overseas and domestic visitors spending in each borough of London. As we do not differentiate between overseas and domestic spending, both data have been summed up (Table 5). Raw data can be found on: http://data.london.gov.uk/datafiles/art-culture/tourism-spend-borough.xls

- Age: The expected number of customers of a borough can be calculated with the Bayes'theorem:

$$
\mathrm{P}(\mathrm{A} \mid \mathrm{B})=\mathrm{P}(\mathrm{B} \mid \mathrm{A}) \cdot \mathrm{P}(\mathrm{A}) / \mathrm{P}(\mathrm{B})
$$

The conditional probability of a person visiting a casino, given his/her age group, is calculated by:

$\mathrm{P}($ visit casino $\mid$ age group $)=\mathrm{P}($ age group $\mid$ visit casino $) \cdot \mathrm{P}($ visit casino $) / \mathrm{P}($ age group $)$ where $\mathrm{P}$ (age group | visit casino) is given in Table 1

$\mathrm{P}($ visit casino $)=4 \%($ Wardle, et al., 2007)

$\mathrm{P}$ (age group): The age distribution of each borough has been found in the London Datastore (http://data.london.gov.uk/). The resident 
[Preprint version] Please cite as : Ishizaka A, Nemery P, Lidouh K, Location selection for the construction of a casino in the Greater London region : a triple multi-criteria approach, Tourism Management, 34(1), 211-220,

age population has been estimated by the UK office for national statistics by interval of 5 years.

- Marital status: The conditional probability of a person visiting a casino, given his/her marital status, is calculated by the Bayes'theorem (13):

$\mathrm{P}($ visit casino $\mid$ marital status $)=\mathrm{P}($ marital status $\mid$ visit casino $) \cdot \mathrm{P}($ visit casino)/P(marital status)

where $\mathrm{P}$ (marital status | visit casino) is given in Table 2

$\mathrm{P}($ visit casino $)=4 \%($ Wardle, et al., 2007$)$

$\mathrm{P}$ (marital status): The marital status in each borough has been found in the London Datastore. The data have been collected during the census 2001. As the data on the casino customers by marital status are less detailed than the census, we have merged the numbers of persons married and living as married. The number of persons separated but still legally married and the divorced persons have also been merged for the same reason.

- Ethnicity: The conditional probability of a person visiting a casino, given his/her ethnicity, is calculated by the Bayes'theorem (13):

$\mathrm{P}($ visit casino $\mid$ ethnicity $)=\mathrm{P}($ ethnicity $\mid$ visit casino $) \cdot \mathrm{P}($ visit casino $) / \mathrm{P}($ ethnicity $)$ where $\mathrm{P}($ ethnicity | visit casino) is given in Table 3

$\mathrm{P}($ visit casino $)=4 \%($ Wardle, et al., 2007$)$

P(ethnicity): The ethnicity in each borough has been found in the London Datastore. The data have been collected during the census 2001. As the data on the casino customers by ethnicity are less detailed than the census, we have merged the numbers into white, black, Asian and other ethnicity groups.

- Qualifications: The conditional probability of a person visiting a casino, given his/her qualifications, is calculated by the Bayes'theorem (13): 
[Preprint version] Please cite as : Ishizaka A, Nemery P, Lidouh K, Location selection for the construction of a casino in the Greater London region : a triple multi-criteria approach, Tourism Management, 34(1), 211-220, 2013

$\mathrm{P}($ visit casino $\mid$ qualifications $)=\mathrm{P}($ qualifications $\mid$ visit casino $) \cdot \mathrm{P}($ visit casino)/P(qualifications)

where $\mathrm{P}$ (qualifications | visit casino) is given in Table 4

$\mathrm{P}($ visit casino $)=4 \%($ Wardle, et al., 2007)

$\mathrm{P}$ (qualifications): The qualifications in each borough have been found in the London Datastore. The data have been collected by the UK Office for National Statistics through a survey in 2008.

- Competitors: The list of large casinos has been found on the Guide on London Casinos (http://www.guidetolondoncasinos.com/). As the number of competitors has to be minimised, we use the formula

$$
\operatorname{Max}-x
$$

where $x$ is the data in the particular borough

Max is the highest value in all the boroughs, in our case 17

- Pay inequalities: The data have been collected by the UK Office for National Statistics through the Annual Survey of Hours and Earnings in 2007. As no data were available for the city of London, we have assumed that it has an equal hourly pay than the highest value in London (i.e. Kensington and Chelsea). As pay inequality has to be minimised, we use formula (14), where $£ 38.00$ is the highest hourly pay of top quartile among all boroughs

- Regeneration: Areas to be regenerated are the deprived areas (Johnson, 2009). Therefore, we use the index of multiple deprivations 2007, which combines a number of indicators, chosen to cover a range of economic, social and housing issues, into a single one. The index has been calculated by the Department for Communities and Local Government. The data have been found in the London Datastore.

- Potential Employment: The number of unemployed persons has been found in the London Datastore. We use the data of the Annual Population Survey 2007. 
[Preprint version] Please cite as : Ishizaka A, Nemery P, Lidouh K, Location selection for the construction of a casino in the Greater London region : a triple multi-criteria approach, Tourism Management, 34(1), 211-220,

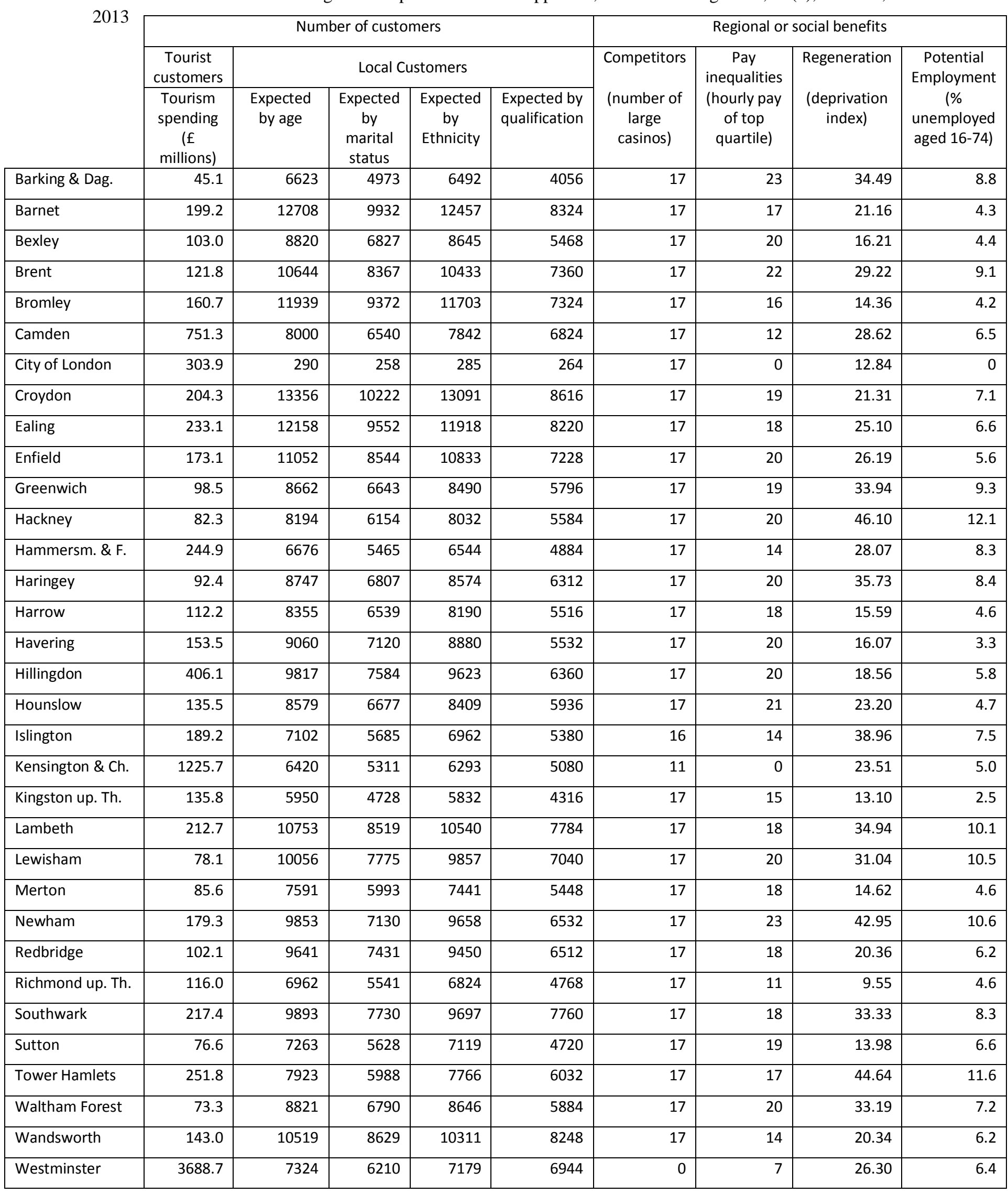

Table 5: Performance matrix used in DECERNS 
[Preprint version] Please cite as : Ishizaka A, Nemery P, Lidouh K, Location selection for the construction of a casino in the Greater London region : a triple multi-criteria approach, Tourism Management, 34(1), 211-220, 2013

\section{Results}

In this section, we present the results obtained with the multi-criteria methods PROMETHEE, TOPSIS and the weighted sum method. Figure 4 represents a ranking with the weighted sum, when the top criterion Number of customers has a weight of 0.6, Regional or social benefits weighs 0.4 and all sub-criteria have an equal weight. This is a particular case. As we do not know the preferences of the stakeholders, we need to consider all the scenarios in a sensitivity analysis.

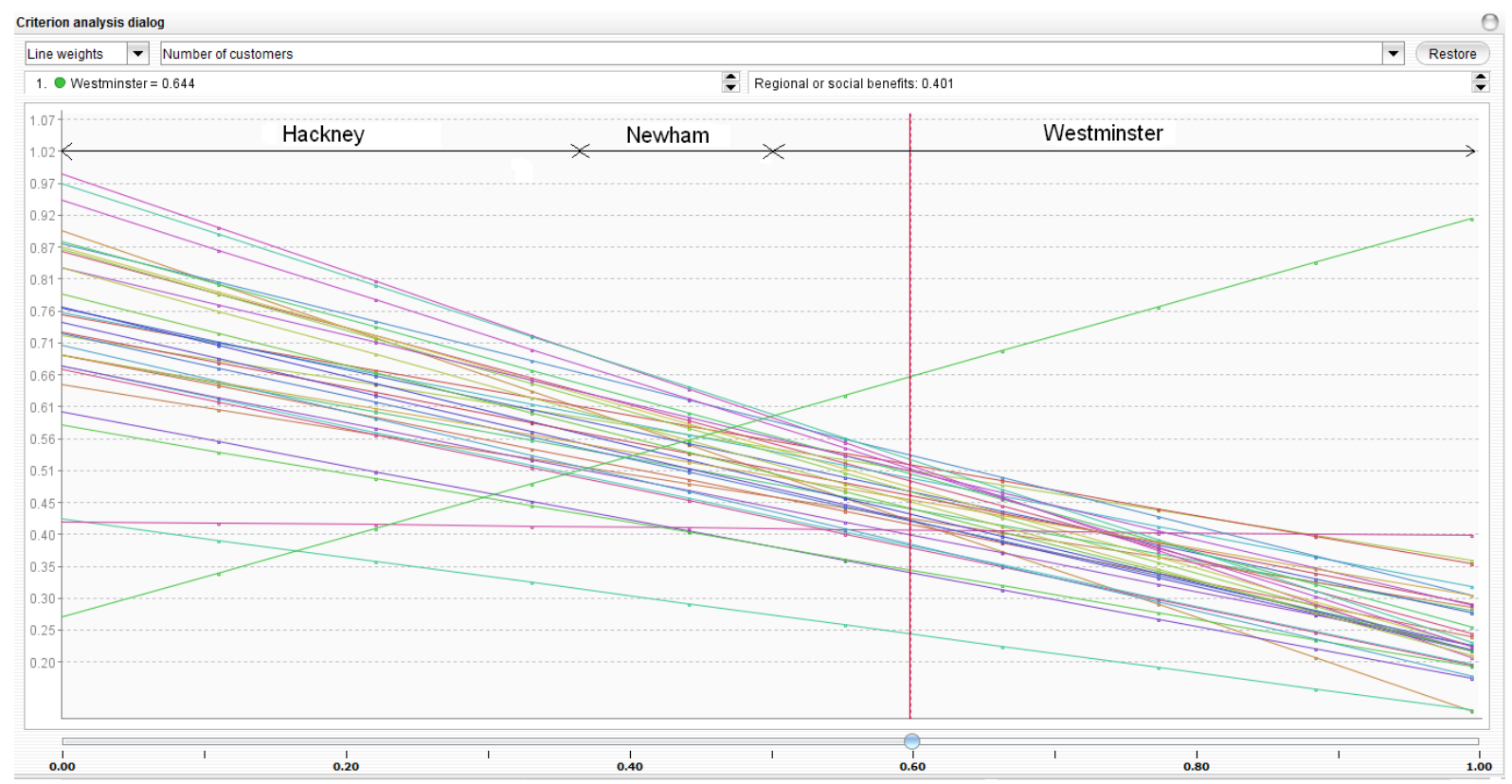

Figure 5 is the sensitivity analysis of the weighted sum. Westminster is the preferred borough to implement a casino if the weight given to the Number of customers is higher than 0.505 . The gap with the runners-up is extremely high. This result is not surprising because Westminster has a very high tourism spending. Indeed, Westminster has a large concentration of London's historic and prestigious landmarks and visitor attractions, including Buckingham Palace and Westminster Abbey. In a compromise solution between Number of customers and Regional or social benefits, Newham would be recommended. If the Regional or social benefits criterion is the most weighted, then Hackney would be preferred (Table 6). The results are very similar for the PROMETHEE method (Figure 6 and Table 7). However, the results are different with TOPSIS (Figure 7 and Table 8). Westminster is by far the preferred borough for a large 
[Preprint version] Please cite as : Ishizaka A, Nemery P, Lidouh K, Location selection for the construction of a casino in the Greater London region : a triple multi-criteria approach, Tourism Management, 34(1), 211-220, 2013

part of the sensitivity analysis. Only when the weight of the criterion Number of customers drops below 0.138, the recommended borough becomes Tower Hamlets and then Hackney. For these scenarios, Newham is the second preferred borough with a very close score. This result are in agreement with (Opricovic \& Tzeng, 2004), who observed that an extreme action would be preferred over a superior compromise (see section 3.4). As the ideal point on the criterion Tourism spending is set by Westminster, the distance to the other alternatives is very high and cannot be compensated by most of the scenarios.

\begin{tabular}{|c|c|c|}
\hline $\begin{array}{c}\text { Weight } \\
\text { Number of customers }\end{array}$ & $\begin{array}{c}\text { Weight } \\
\text { Regional or social benefits }\end{array}$ & Winner \\
\hline from 1 to 0.506 & from 0 to 0.495 & Westminster \\
\hline from 0.506 to 0.370 & from 0.495 to 0.627 & Newham \\
\hline from 0.370 to 0 & from 0.628 to 1 & $\begin{array}{c}\text { Hackney } \\
\text { (Newham is second) }\end{array}$ \\
\hline
\end{tabular}

Table 6: Results for the weighted sum method

\begin{tabular}{|c|c|c|}
\hline $\begin{array}{c}\text { Weight } \\
\text { Number of customers }\end{array}$ & $\begin{array}{c}\text { Weight } \\
\text { Regional or social benefits }\end{array}$ & Winner \\
\hline from 1 to 0.504 & from 0 to 0.496 & Westminster \\
\hline from 0.504 to 0.371 & from 0.497 to 0.630 & Newham \\
\hline from 0.371 to 0 & from 0.631 to 1 & $\begin{array}{c}\text { Hackney } \\
\text { (Newham is second) }\end{array}$ \\
\hline
\end{tabular}

Table 7: Results for the PROMETHEE method

\begin{tabular}{|c|c|c|}
\hline $\begin{array}{c}\text { Weight } \\
\text { Number of customers }\end{array}$ & $\begin{array}{c}\text { Weight } \\
\text { Regional or social benefits }\end{array}$ & Winner \\
\hline from 1 to 0.135 & from 0 to 0.862 & Westminster \\
\hline from 0.135 to 0.111 & from 0.863 to 0.888 & $\begin{array}{c}\text { Tower Hamlets } \\
\text { (Newham is second) }\end{array}$ \\
\hline from 0.111 to 0 & from 0.889 to 1 & $\begin{array}{c}\text { Hackney } \\
\text { (Newham is second) }\end{array}$ \\
\hline
\end{tabular}

Table 8: Results for TOPSIS 
[Preprint version] Please cite as : Ishizaka A, Nemery P, Lidouh K, Location selection for the construction of a casino in the Greater London region : a triple multi-criteria approach, Tourism Management, 34(1), 211-220, 2013

PROMETHEE and the weighted sum method have a consensual recommendation, which corresponds to the real taken decisions:

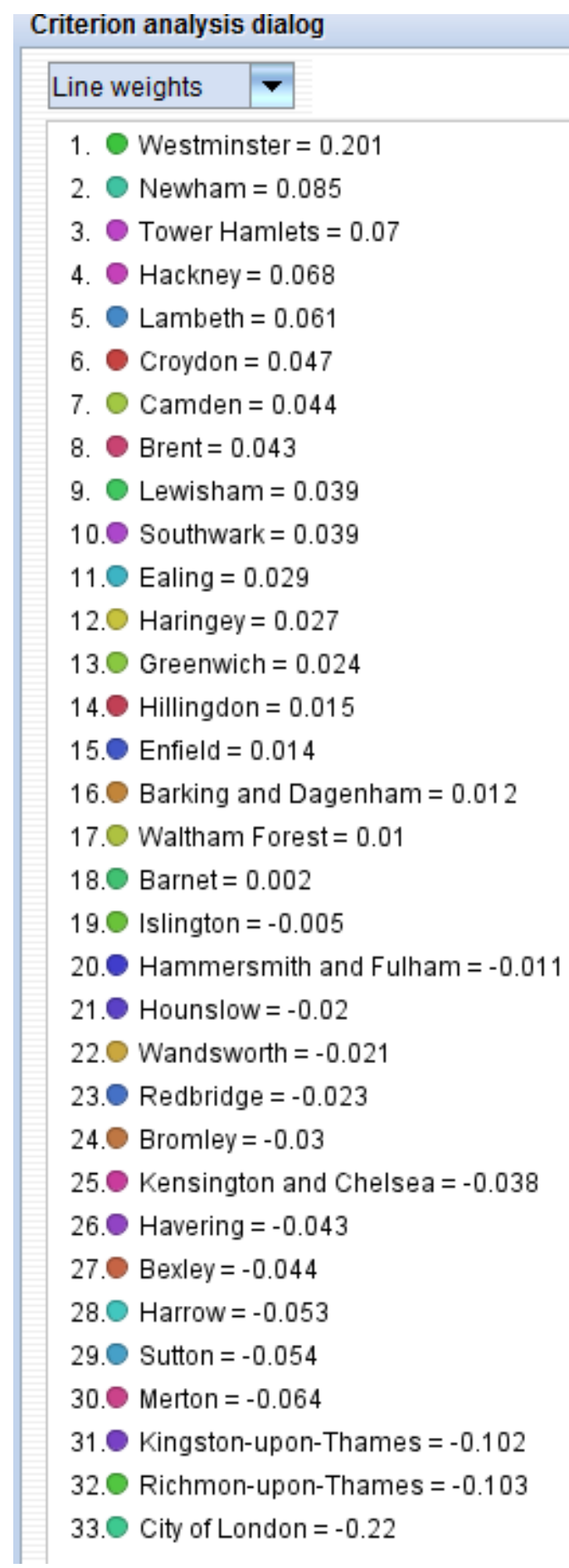

Figure 4: PROMETHEE ranking of boroughs with the weights Number of customers = 0.6 and Regional or social benefits $=0.4$ 
[Preprint version] Please cite as : Ishizaka A, Nemery P, Lidouh K, Location selection for the construction of a casino in the Greater London region : a triple multi-criteria approach, Tourism Management, 34(1), 211-220, 2013

- If the purpose of a casino is to maximise its financial profits, then the best location is Westminster.

- If a compromise between regeneration and social benefits and its financial profits is searched as in the Casino Advisory Panel (CAP, 2007), Newham is the best location.

TOPSIS arrives at a different conclusion than that taken by CAP. In both configurations, it will recommend Westminster.

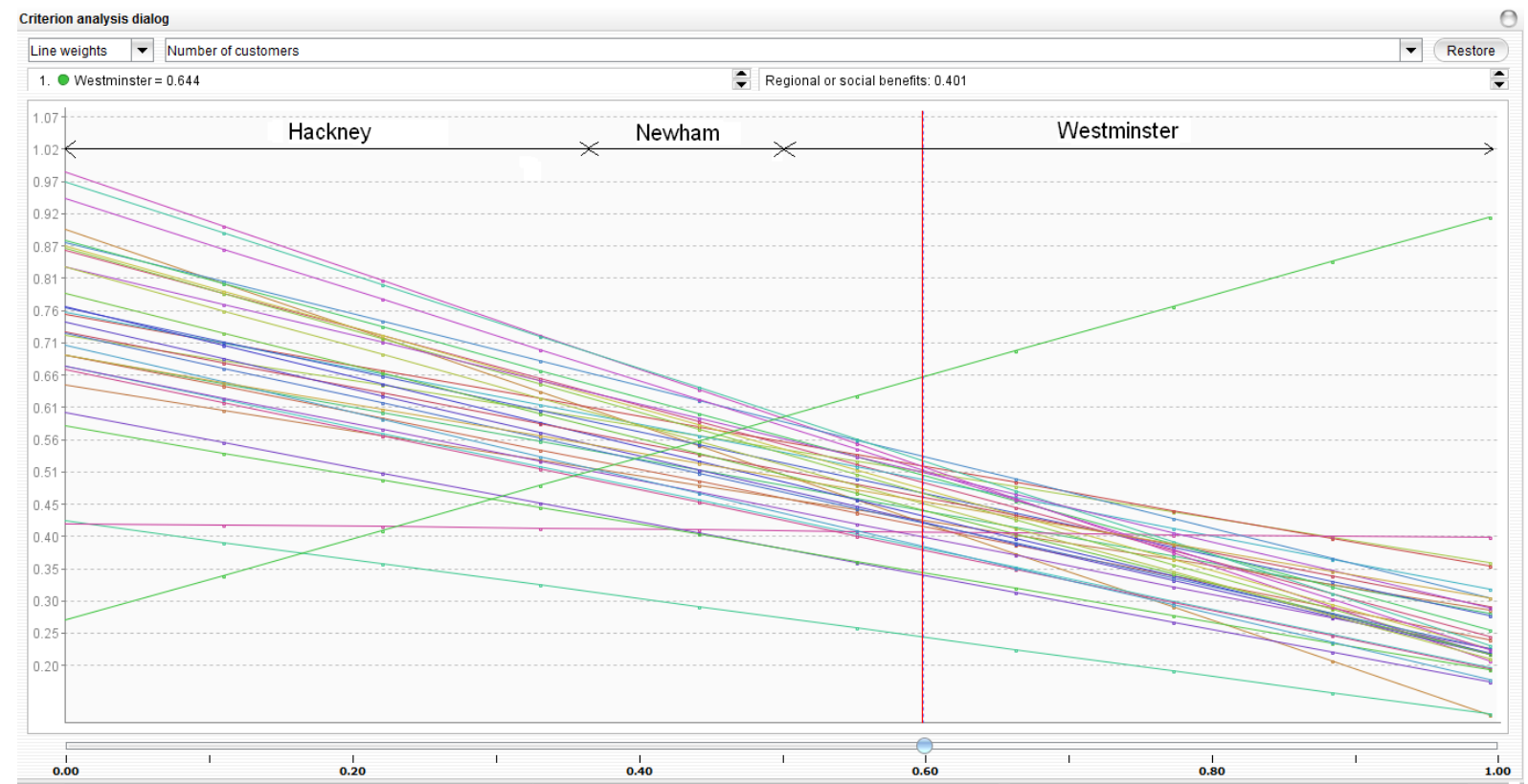

Figure 5: Sensitivity analysis with the weighted sum method

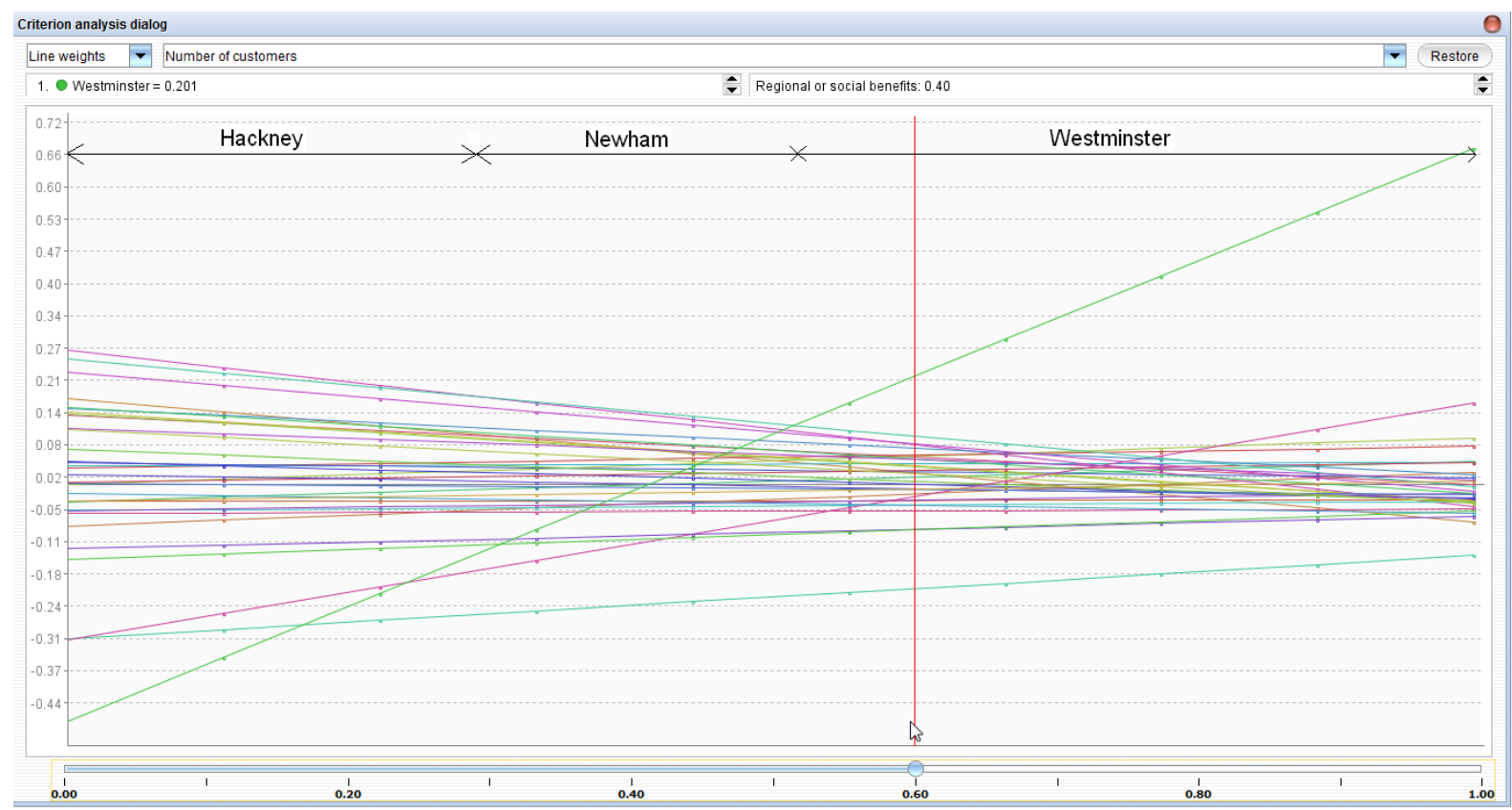


[Preprint version] Please cite as : Ishizaka A, Nemery P, Lidouh K, Location selection for the construction of a casino in the Greater London region : a triple multi-criteria approach, Tourism Management, 34(1), 211-220, 2013

Figure 6: Sensitivity analysis with PROMETHEE

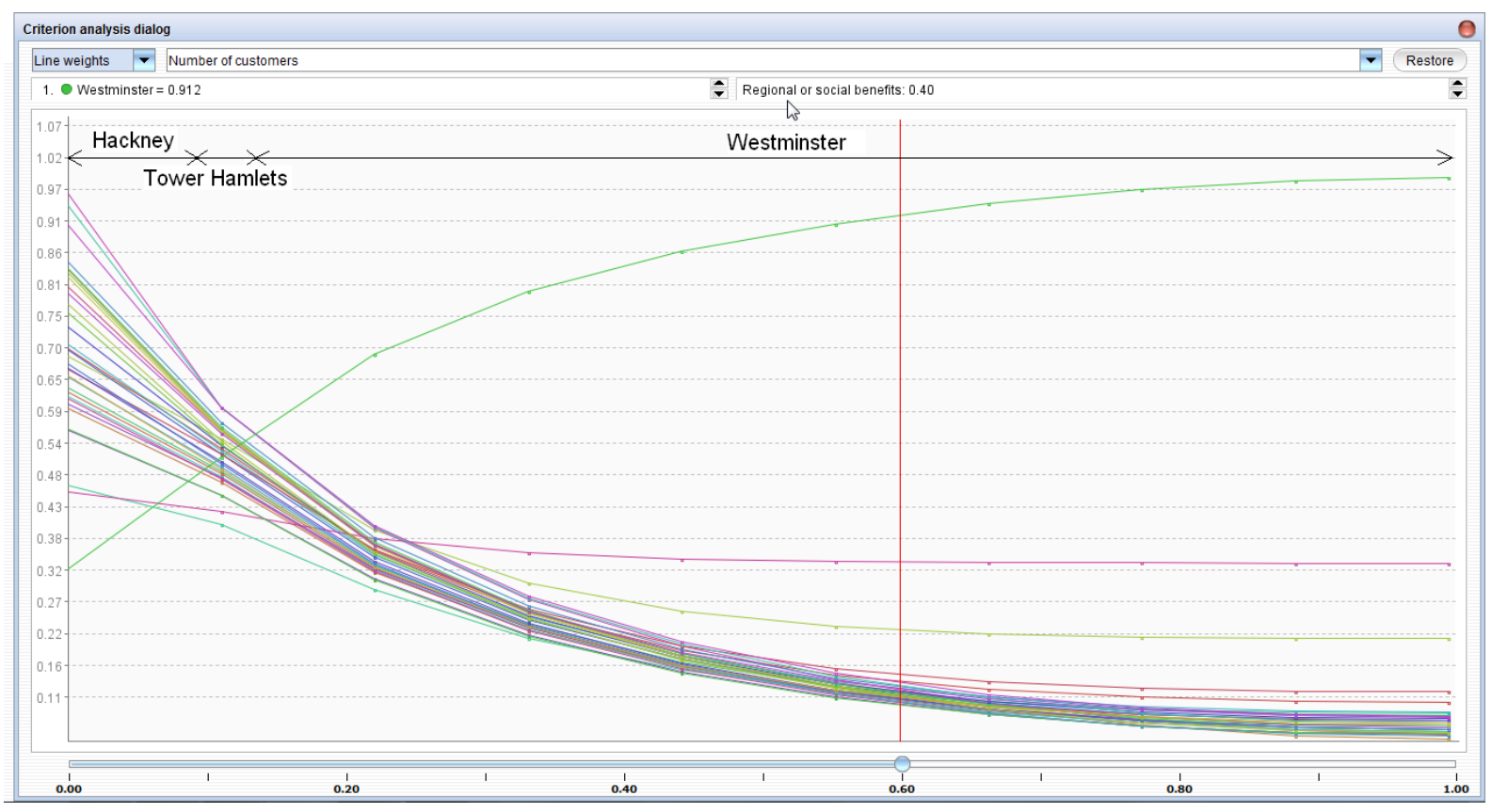

Figure 7: Sensitivity analysis with TOPSIS

\section{Conclusion}

Since the Gambling Act 2005 creates a new framework for the regulation of all forms of gambling activities in United Kingdom, there has been a debate around the location of new casinos. This paper has considered this complex problem in Greater London through three multi-criteria analysis. Three boroughs stand out: Westminster for its high number of possible customers, Hackney for its needs of regional and social benefits and Newham for a compromise between both. It is probably not surprising that only Westminster and Newham have submitted a proposal when the Gambling Act 2005 permitted the construction of new casinos. Even if Hackney is in need of regeneration, a casino would not be helpful as it would have attracted a low number of customers. Westminster had a proven history of successful casinos in its area. However these casinos were built in an era where the unique criterion considered was to maximise its financial profit. Recently, the modern gambling industry has evolved and casinos are now accepted as a driver for regeneration of deprived areas. The Casino Advisory Panel had clearly stated that the regeneration criteria would be used in awarding the licence for a new casino. In 2007, Newham was recommended by the Casino Advisory Panel. This choice is in agreement with the PROMETHEE and the Weighted Sum Method 
[Preprint version] Please cite as : Ishizaka A, Nemery P, Lidouh K, Location selection for the construction of a casino in the Greater London region : a triple multi-criteria approach, Tourism Management, 34(1), 211-220, 2013

suggestions. TOPSIS suggests a different recommendation, where the extreme action is preferred over the superior compromise. Opricovic and Tzeng (2004) have already observed this phenomenon on a simple theoretical example of three actions and two criteria.

The case study presented here is a real decision problem and must hence be taken very seriously. From the perspective of economists, decision making is almost always about making compromises. Trying to reach a better outcome in one dimension is often at the expense of achieving a worse outcome in another dimension. For instance, the production cost of a firm can often only be lowered at the expense of producing lower quality output. It is obvious to most consumers that if one chooses a lower-priced product (superior in the price dimension), it is usually at a lower quality (the other dimension): one gets what one pays for. A good decision-maker will typically have to correctly trade off one dimension against another. If a decision aid like the TOPSIS that may recommend extremes, which are good in only one respect, it will fail in its purpose.

\section{References}

Afifi, T., Cox, B., Martens, P., Sareen, J., \& Enns, M. (2010). Demographic and social variables associated with problem gambling among men and women in Canada. Psychiatry Research, 178, 395-400.

AGA. (2012). The AGA Survey of Casino Entertainment. http://www.americangaming.org/files/aga/uploads/docs/sos/aga_sos_2012_web.pdf (accessed 15th May 2012). Washington: American Gaming Association.

Andersen, A. (1996). Economic impacts of casino gaming in the United States. In prepared for the American Gaming Association (Vol. 1: Macro Study). Washington.

Authority, G. L. (2009). The London Plan: Spatial Development Strategy for Greater London. In (Vol. accessed the 10th December 2010): http://www.london.gov.uk/shaping-london/london-plan/docs/london-plan.pdf.

Barrow, C., Borges, D., \& Galipeau, N. (2004). Economic \& fiscal impact analysis for a West Warwick resort casino. In Economic Research Series No. 51 (pp. 1-85). North Dartmouth: University of Massachusetts Dartmouth.

Behzadian, M., Kazemzadeh, R. B., Albadvi, A., \& Aghdasi, M. (2010). PROMETHEE: A comprehensive literature review on methodologies and applications. European Journal of Operational Research, 200, 198-215.

Brans, J.-P. (1982). L'ingénierie de la décision: Elaboration d'instruments d'aide à la décision. In R. Nadeaeu \& M. Landry (Eds.), L'aide à la décision: Nature, Instruments et Perspectives d'Avenir (pp. 183-213). Québec: Presse de l'Université de Laval.

Brans, J.-P., \& Mareschal, B. (2005). PROMETHEE methods. In J. Figueira, S. Greco \& M. Ehrgott (Eds.), Multiple Criteria Decision Analysis:State of the Art Surveys. New York: Springer. 
[Preprint version] Please cite as : Ishizaka A, Nemery P, Lidouh K, Location selection for the construction of a casino in the Greater London region : a triple multi-criteria approach, Tourism Management, 34(1), 211-220, 2013

Brans, J.-P., \& Vincke, P. (1985). A preference ranking organisation method. Management Science, 31, 647-656.

Burmania, D. (2010). November Casino Revenue. In (pp. http://www.colorado.gov/cs/Satellite/Rev-Gaming/RGM/1213781235470 (accessed the 1213781235410th January 1213781232010)). Golden: Colorado Department of Revenue: Division of Gaming.

CAP. (2007). Final report of the casino advisory panel. In. London.

Curran, D., \& Scarpitti, F. (1991). Crime in Atlantic City: do casinos make a diffference? Deviant Behavior: An Interdisciplinary Journal, 12, 431-449.

Farahani, R. Z., SteadieSeifi, M., \& Asgari, N. (2010). Multiple criteria facility location problems: A survey. Applied Mathematical Modelling, 34, 1689-1709.

Felsenstein, D., Littlepage, L., \& Klacik, D. (1999). Casino gambling as local growth generation: playing the economic development game in reverse? Journal of Urban Affairs, 21, 409-421.

Friedman, J., Hakim, S., \& Weinblatt, J. (1989). Casino gambling as a "growth pole" strategy and its effect on crime. Journal of Regional Science, 29, 615-623.

Goodman, R. (1995). The luck business: the devasting consequences and broken promises of America's gambling explosion. New York: The Free Press.

Greater London Authority. (2009). The London plan: Spatial development strategy for Greater London. http://www.london.gov.uk/shaping-london/londonplan/docs/london-plan.pdf (accessed 15th May 2012). London.

Grinols, E., \& Mustard, D. (2006). Casinos, Crime, and Community Costs. The Review of Economics and Statistics, 88, 28-45.

Hakim, S., \& Buck, A. (1989). Do casinos enhance crime? Journal of Criminal Justice, 17, 409-416.

Hannigan, J. (2007). Casino Cities. Geography Compass, 1, 959-975.

Harrah's. (2000). We know what our customers like. Annual Report http://www.kenshippdesign.com/pdfs/HAR00.pdf (accessed 15th May 2012). Las Vegas: Harrah's Entertainment Group

Heraty, M. (2006). Casino advisory panel formal proposal. In (pp. http://webarchive.nationalarchives.gov.uk/+/http://www.culture.gov.uk/CAP/propo sals/Newham.pdf). Newham.

Hodgson, B. (2006). Westminster City Council proposal for further casinos to the casino advisory panel. In (pp.

http://webarchive.nationalarchives.gov.uk/+/http://www.culture.gov.uk/CAP/propo sals/Westminster.pdf). Westminster.

Hwang, C.-L., \& Yoon, K. (1981). Multiple Attribute deciison Making: Methods and Applications. New York: Springer-Verlag.

Johnson, B. (2009). The London Plan. In Consultation draft deplacement plan. London.

Kang, S., Lee, C., Yoon, Y., \& Long, P. (2008). Resident perception of the impact of limited-stakes community-based casino gaming in mature gaming communities. Tourism Management, 29, 681-694.

Kessler, R., Hwang, I., LaBrie, R., Petukhova, M., Sampson, N., Winters, K., \& Shaffer, H. (2008). DSM-IV pathological gambling in the National Comorbidity Survey Replication. Psychological Medicine, 38, 1351-1360

Koo, J., Rosentraub, M., \& Horn, A. (2007). Rolling the dice? Casinos, tax, revenues, and the social costs of gaming. Journal of Urban Affairs, 29, 367-381.

Lai, Y.-J., Liu, T.-Y., \& Hwang, C.-L. (1994). TOPSIS for MODM. European Journal of Operational Research, 76, 486-500. 
[Preprint version] Please cite as : Ishizaka A, Nemery P, Lidouh K, Location selection for the construction of a casino in the Greater London region : a triple multi-criteria approach, Tourism Management, 34(1), 211-220, 2013

Lee, C.-K., Kang, S., Long, P., \& Reisinger, Y. (2010). Residents' perceptions of casino impacts: A comparative study. Tourism Management, 31, 189-201.

Leven, C., Phares, D., \& Louishomme, C. (1998). The economic impact of gaming in Missouri. In (pp. http://flash.lakeheadu.ca/ mshannon/impact/Gambling.pdf (accessed the 10th January 2010)). St-Louis: Civic progress.

Long, P. (1996). Early impacts of limited stakes casino gambling on rural community life. Tourism Management, 17, 341-353.

Mareschal, B., De Smet, Y., \& Nemery, P. (2008). Rank Reversal in the PROMETHEE II Method : Some New Results. In IEEE 2008 International Conference on Industrial Engineering and Engineering Management. Singapore.

Marshall, K., \& Wynne, H. (2004). Against the odds: a profile of at-risk and problem gamblers. Canadian Social Trends, 73, 25-29.

McBride, O., Adamson, G., \& Shevlin, M. (2010). A latent class analysis of DSM-IV pathological gambling criteria in a nationally representative British sample. Psychiatry Research, 178, 401-407.

Mcmahon, L., \& Lloyd, G. (2006). 'Rien ne va Plus.' casino developments and land use planning? Planning Practice and Research, 21, 257 - 266.

Newham Council. (2006). Formal proposal Newham council. http://webarchive.nationalarchives.gov.uk/20090213101914/http://culture.gov.uk/c ap/proposals/Newham.pdf (accessed 15th May 2012).

Opricovic, S., \& Tzeng, G.-H. (2004). Compromise solution by MCDM methods: A comparative analysis of VIKOR and TOPSIS. European Journal of Operational Research, 156, 445-455.

Orford, J., Sproston, K., \& Erens, B. (2003). SOGS and DSM-IV in the British Gambling Prevalence Survey: Reliability and Factor Structure. International Gambling Studies, 3, 53 - 65.

Park, M., \& Stokowski, P. (2010). Casino Gaming and Crime: Comparisons among Gaming Counties and Other Tourism Places. Journal of Travel Research, advance online publication, doi:10.1177/0047287510363616.

Perdue, R., Long, P., \& Kang, Y. (1999). Boomtown tourism and resident quality of life: the marketing of gaming to host community residents. Journal of Business Research, 44, 165-177.

Research, G. (2009a). Las Vegas visitor profile: annual report. In. Las Vegas: Las Vegas Convention And Visitors Authority.

Research, G. (2009b). Laughlin visitor profile: annual report. In. Las Vegas: Laughlin Visitors Bureau.

ReVelle, C., \& Eiselt, H. (2005). Location analysis: A synthesis and survey. European Journal of Operational Research, 165, 1-19.

ReVelle, C., Eiselt, H., \& Daskin, M. (2008). A bibliography for some fundamental problem categories in discrete location science. European Journal of Operational Research, 184, 817-848.

Roehl, W. (1999). Quality of life issues in a casino destination. Journal of Business Research, 44, 223-229.

Rose, A. (1998). The regional economic impacts of casino gambling: assessment of the literature and establishment of a research agenda. Prepared for National Gambling Impact Study Commission http://govinfo.library.unt.edu/ngisc/reports/ecoimprpt.pdf (accessed 15th May 2012).

Smith, H., Laporte, G., \& Harper, P. (2009). Locational analysis: highlights of growth to maturity. Journal of the Operational Research Society, 60, 140-148. 
[Preprint version] Please cite as : Ishizaka A, Nemery P, Lidouh K, Location selection for the construction of a casino in the Greater London region : a triple multi-criteria approach, Tourism Management, 34(1), 211-220,

2013

Sproston, K., Erens, B., \& Orford, J. (2000). Gambling behaviour in Britain: results from the British gambling prevalence survey. In N. C. f. S. Research (Ed.). London.

Stitt, G., Nichols, M., \& Giacopassi, D. (2005). Perception of casinos as disruptive influences in USA communities. International Journal of Tourism Research, 7, 187-200.

Sullivan, T., Yatsalo, B., Grebenkov, A., \& Linkov, I. (2009). Decision evaluation for complex risk network systems (DECERNS) software tool. In A. Marcomini, G. Suter II \& A. Critto (Eds.), Decision Support Systems for Risk-Based Management of Contaminated Sites (pp. 257-275). New York: Springer US.

Vincke, P. (1992). Multicriteria Decision-Aid. Chichester: John Willey \& Sons.

Walker, M., \& Dickerson, M. (1996). The prevalence of problem and pathological gambling: A critical analysis. Journal of Gambling Studies, 12, 233-249.

Wardle, H., Sproston, K., Orford, J., Erens, B., Griffiths, M., Constantine, R., \& Pigott, S. (2007). British gambling prevalence survey 2007. In N. C. f. S. Reseach (Ed.). London.

Yoon, K. (1980). Systems selection by multiple attribute decision making. Kansas State University.

Zenke, D., \& Shoemaker, S. (2009). An overview of consumer non-problem gaming research. Worldwide Hospitality and Tourism, 1, 355-366. 